Volume. 5 Number. 1

Period: January - June 2021; page 17-25

p-ISSN : 2580-1112; e-ISSN : 2655-6669

Jurnal Ilmiah Keperawatan Orthopedi

Copyrighr@2020

(JIKO)

The author owns the copyright of this article

journal homepage: https://ejournal.akperfatmawati.ac.id

DOI : $10.46749 /$ jiko.v5i1.57

Article history:

Received: February 26, 2021

Revised: February 28, 2021

Accepted: March 03, 2021

\title{
Liquid Restriction for Patients With Chronic Kidney Disease to Prevent The Risk of Fluid Overload
}

\author{
Zahri Darni ${ }^{1}$, Maryani Eka Sasmita ${ }^{2}$ \\ Fatmawati Academy of Nursing, Jakarta-Indonesia. \\ e-mail: zahri.darni@akperfatmawati.ac.id
}

\begin{abstract}
Chronic Kidney Disease is an end stage kidney disease which is a progressive and irreversible impairment of kidney function in which the body's ability to fail to maintain metabolism. This disease is a complication of hypertension, diabetes mellitus, pyelonephritis and acute renal failure. This study aims to describe the implementation of fluid restriction interventions to address the risk of fluid volume overload. The method used is descriptive with a case study approach with a sample of two patients. Methods of data collection by interview, observation, physical examination and documentation study. The data obtained were analyzed descriptively to describe changes in blood pressure, pulse frequency, respiratory rate, temperature, body weight and edema. The results of the case study showed no edema, blood pressure in subject I from $158 / 78 \mathrm{mmHg}$ to $135 / 89 \mathrm{mmHg}$, subject II from $141 / 80 \mathrm{mmHg}$ to $128 / 78 \mathrm{mmHg}$, pulse rate, respiratory rate, temperature within normal limits and body weight both subjects there is no increase. This case study recommends that nurses maintain fluid restriction settings to address the risk of fluid volume overload in Chronic Kidney Disease patients.
\end{abstract}

Key words: Chronic Kidney Disease, fluid restriction, risk of excess fluid volume.

\section{Preliminary}

The kidney is an important organ in the body as a homeostatic by regulating fluid volume, osmotic and acid-base balance, excretion of metabolic waste, hormonal and metabolic regulatory systems.

The process of regulating this need for balance begins with the ability of the kidney, such as the glomerulus, to filter blood. If the kidneys are no longer able to perform filtration or filtering of the glomerulus, the nephrons in the glomerulus will experience failure in filtering which is called kidney failure (Hidayat, 2012).

Kidney failure can change the balance of fluids and electrolytes. Kidney failure will result in abnormal retention of sodium, chloride, potassium and water in the extracellular fluid. Plasma levels in metabolic waste products, such as BUN (Blood Urea Nitrogen) and creatinine will increase because the kidneys are unable to filter and excrete these metabolic waste products. This increase is either toxic or toxic to the cellular process. There is a disturbance in the renal compensation mechanism that is usually done, such as bicarbonate reabsorption can no longer be available, so that the body's ability to restore acid and alkaline balance is limited (Potter \& Perry, 2006).

The incidence of kidney problems is still quite high and is a health problem not 
only in Indonesia, but even in developed countries. Global Burden of Disease (2010 in Ulfah, Yuniarti and Rahayuni, 2018), states that Chronic Kidney Disease is ranked 18th in the list of causes of death worldwide. Between 8 and $10 \%$ of the adult population has kidney damage and every year millions of people die from complications related to Chronic Kidney Disease. In Japan in 2005 the number of patients with kidney failure in the adult population was 13.3 million, which is about $13 \%$.

The prevalence rate of kidney failure patients in Japan is almost the same as in the United States, where the incidence of Chronic Kidney Disease (CKD) increases at $>60$ years of age (Imai E, at al, 2009 in Jamiatun, Elegia \& Syarif, 2015).

Based on research Perhimpunan Nefrologi Indonesia (PERNEFRI) in 2005 that one-eighth of Indonesia's population, or about 25 million people have impaired kidney function. The results obtained through Basic Health Research (2013) show that the prevalence of CKD based on interviews diagnosed by doctors increases with age, the highest group in the age group is $\geq 75$ years $(0.6 \%)$. The prevalence in men $(0.3 \%)$ is higher than women $(0.2 \%)$, the prevalence is higher in rural communities $(0.3 \%)$, higher in patients who do not attend school (0.4\%), and the employment rate is higher for selfemployed workers, farmers/fishermen/laborers $(0.3 \%)$.

Patients with CKD need proper medication and care. If not treated properly, it will cause complications such as anemia, hypertension, ventricular hypertrophy, pericardial effusion, dilated cardiomyopathy, loss of consciousness, itching and bone disease. According to Suharyanto and Madjid (2009), the treatment of patients with $\mathrm{C} \mathrm{KD}$ can be divided into two phases of conservative measures and dialysis or transplantation of the kidney. Conservative measures aim to relieve or slow down impaired kidney function, namely by limiting fluids and dietary regulation or diet, for example, protein diet as much as 20-40 grams/day, low sodium as much as 1-2 grams/day, and potassium as much as $40-80 \mathrm{mEq} / \mathrm{day}$ which is useful for normalizing abnormalities and slowing down the occurrence of kidney failure.

The role of the nurse is very important in helping to manage the fluid restrictions that have been established. According to Suharyanto (2009), free intake can cause excessive circulation load and edema, while too low intake results in dehydration, hypotension and impaired kidney function. Therefore, patients with CKD need to control and limit the amount of fluid intake that has been determined. In the clinical assessment aspect of the patient from fluid restriction can be seen from the initial body weight and final body weight. There is a decrease and increase in body weight indicating a rapid presence of $5 \%$ or more of the total body weight, identifying a deficit or excess fluid volume from moderate to severe (Berman \& Synder, 2010).

Research conducted by Jamiatun, Michele and Sharif in 2015 didapatkan result there is a significant relationship between adherence to the old hemodialysis $(\mathrm{p}=0.039)$, compliance with knowledge $(\mathrm{p}=0.028)$, compliance with family support $(\mathrm{p}=0.013)$. Whereas in this study, the most significant is that good family support has a chance to obey 3.563 times compared to respondents who received poor family support. Another research conducted by Ulfah, Yuniarti, and Rahayuni (2018), obtained results was no significant difference of knowledge restriction of fluid intake before and after nutrition conseling using leaflets $\mathrm{p}<0.05$ $(\mathrm{p}=0.001)$.

Based on the above background, the authors are interested in knowing how the implementation of fluid restriction in Chronic Kidney Disease patients to overcome the risk of excess fluid volume. 


\section{Method}

The research method is descriptive with a case study approach to get an overview of the implementation of fluid restriction in patients with chronic kidney disease to prevent excess fluid volume.

The case study subjects consisted of two patients with chronic kidney disease with inclusion criteria: patients with composmentis awareness, patients who had been diagnosed with chronic kidney disease, had a risk of edema or edema, and patients who had fluid restriction.

The exclusion criteria were patients with decreased consciousness, patients who were not diagnosed with chronic kidney disease, no edema, and patients who did not get fluid restrictions.

Methods of data collection through interviews, observation for monitoring fluid intake and output, weighing and measuring blood pressure, respiratory rate, pulse frequency and temperature. The data collection instrument used the medical surgical nursing assessment format developed by the author.

This research was conducted at Fatmawati Hospital, Jakarta in March 2019. Data analysis was conducted descriptively to describe changes in blood pressure, pulse frequency, respiratory rate, temperature, body weight and edema.

\section{Result \\ Subject I}

The 54 year old patient comes from the Betawi tribe, his last education is junior high school. The patient lives on Jl. Kebagusan Wates Ragunan Ps. Minggu. The patient was admitted to Fatmawati Hospital on March 1, 2019 with a medical diagnosis of CKD on HD and Anemia gravis.

Current medical history: the patient says weakness, dizziness and nausea and when urinating only a little. The patient has a history of hypertension since 2009 and controls to the Distric Helath Center if there are complaints that are felt such as dizziness and getting $10 \mathrm{mg}$ of amlodipine.

Laboratory tests of $20 \%$ hematocrit, 147 thousand platelets/ul, $111 \mathrm{mg} / \mathrm{dl}$ of blood urea, $8.9 \mathrm{mg} / \mathrm{dl}$ of creatinine, 114 $\mathrm{mg} / \mathrm{dl}$ of blood sugar, $125 \mathrm{mmol} / \mathrm{dl}$ of sodium blood, $4.94 \mathrm{mmol} / \mathrm{l}$ potassium, 105 chloride $\mathrm{mmol} / \mathrm{l}$, CCT results in subject I: $5.5 \mathrm{~mL} / \mathrm{minute} / 1.73 \mathrm{~m} 2$ (N: 90 $120 \mathrm{~mL} /$ minute $/ 1.73 \mathrm{~m} 2$ ) is stage 5 , namely the end stage.

Drinking patterns at home, patients say they rarely drink 2 glasses of water $(250 \mathrm{cc})$ a day and often consume 1 bottle of bottled drinks in one day, urinate 8-9 times/day, light brown color, 50-70 cc. The drinking pattern when in the hospital the patient has been given a fluid restriction of $600 \mathrm{cc} / \mathrm{day}$ but the patient does not know how to regulate it and there is no excessive thirst, urinating in the hospital 6-7 times/day, light brown color and urine that comes out 70-150 cc.

Before getting sick $50 \mathrm{~kg}$, current weight $46 \mathrm{~kg}$ with $155 \mathrm{~cm}$ height. Pulse rate $84 \mathrm{x} /$ minute with regular rhythm and strong pulse, blood pressure 169/98 $\mathrm{mmHg}$, warm skin temperature, pale skin color, capillary filling $<3$ seconds, no edema in the upper or lower limbs, $84 \mathrm{x} /$ minute apical pulse rate with rhythm regular. Intake (drinking) 1100 cc, output $1510 \mathrm{cc}$ (urine $1010 \mathrm{cc}, 500 \mathrm{cc}$ IWL), balance $-410 \mathrm{cc}$.

The patient complains of urinating 8$9 x /$ day but the discharge is small. Non parenteral drugs: bioprexum $10 \mathrm{mg} / 24$ hours and amlodipine $10 \mathrm{mg} / 24$ hours, , get $1500 \mathrm{kcal}$ of kidney diet, hemodialysis therapy twice a week on Wednesday and Saturday and get fluid restriction of 600 cc/24 hours.

\section{Subject II}

The patient is 49 years old, comes from Javanese ethnicity, his last education is elementary school. The patient lives in Depok Baru. Patients entered Fatmawati Hospital on March 4, 2019 with a medical 
diagnosis of CKD on $\mathrm{HD}$, type 2 diabetes mellitus with gangrene in the right leg.

Current medical history: patients said their tiredness and excessive thirst and there is a diabetic ulcer on the right foot since five months ago. The patient had a history of type 2 diabetes mellitus since 2007 and CKD since 2012, the patient received hemodialysis therapy 3 times at the Zahira clinic for 1 month ago.

Laboratory tests of $22 \%$ hematocrit, 740 thousand platelets/ul, $62 \mathrm{mg} / \mathrm{dl}$ of blood urea, $2.5 \mathrm{mg} / \mathrm{dl}$ of creatinine, 157 $\mathrm{mg} / \mathrm{dl}$ of blood sugar, $125 \mathrm{mmol} / \mathrm{l}$ sodium blood, $5.48 \mathrm{mmol} / \mathrm{l}$ potassium, 102 $\mathrm{mmol} / \mathrm{l}$ chloride. CCT results: 23.2 $\mathrm{mL} /$ minute $/ 1.73 \mathrm{~m}^{2}$ and it is stage 4 , namely chronic renal failure.

The drinking pattern at home, the patient said that he rarely drank only 1 large glass of water $(600 \mathrm{cc})$ in a day and when working consume 3 cups of coffee a day and beverages a day 1 bottle (500 cc). The pattern of eliminating urination at home is 9-12x / day, dark brown and frothy, the urine is $250-480 \mathrm{cc}$.

The drinking pattern at the hospital, the patient has been given a fluid restriction of $600 \mathrm{cc} /$ day and how to regulate it using a small bottle measuring $300 \mathrm{cc}$. The patient said that the frequency of urination was $8-9 x /$ day in the hospital, light brown and bubbly and the urine was $220-350 \mathrm{cc}$. The patient's pulse rate was $85 \mathrm{x} /$ minute with a regular rhythm and weak pulse, blood pressure of 141/80 $\mathrm{mmHg}$, warm skin temperature, pale skin color, capillary filling $<3$ seconds, no edema in the upper and lower limbs, face, and periorbital.

Apical beat rate $85 \mathrm{x} /$ minute with regular rhythm. Intake (drinking) $1170 \mathrm{cc}$, output $1350 \mathrm{cc}$ (urine $850 \mathrm{cc}$, IWL 500 cc) balance -230 , no change in urinary pattern. Pee with light brown color. The patient received 5 units of novorapid, received $1500 \mathrm{kcal}$ of kidney diet and diabetes mellitus, hemodialysis therapy every Friday and received fluid restriction of $600 \mathrm{cc}$ per 24 hours.

Actions taken are providing education about the care of CKD patients and drinking $600 \mathrm{cc}$ a day using flipchart media which is attended by the family (husband, wife and children). At the end of the counseling, the authors provide leaflets to help patients remind patients about CKD treatment if the patient forgets, and measure vital signs (blood pressure, respiratory rate, pulse rate and temperature), weigh body weight every day, provide an intake output sheet per 24 hours and monitor for edema.

Table 1 Results of intake output per 24 hours

\begin{tabular}{|c|c|c|c|c|c|c|}
\hline \multirow{2}{*}{ Rated aspect } & \multicolumn{3}{|c|}{ Subject I } & \multicolumn{3}{|c|}{ Subject II } \\
\hline & 1 & 2 & 3 & 1 & 2 & 3 \\
\hline Intake (cc) & 550 & 600 & 600 & 600 & 600 & 600 \\
\hline \multirow{4}{*}{$\begin{array}{l}\text { Oral fluids }+ \text { food } \\
\text { fluids per } 24 \text { hours } \\
\qquad(500 \mathrm{cc})\end{array}$} & + & + & + & + & + & + \\
\hline & 500 & 500 & 500 & 500 & 500 & 500 \\
\hline & $=$ & $=$ & $=$ & $=$ & $=$ & $=$ \\
\hline & 1050 & 1100 & 1100 & 1100 & 1100 & 1100 \\
\hline \multirow{5}{*}{$\begin{array}{c}\text { Output cc } \\
\text { Urine + IWL (500) }\end{array}$} & 975 & 850 & 925 & 1020 & 1150 & 1090 \\
\hline & + & + & + & + & + & + \\
\hline & 500 & 500 & 500 & 500 & 500 & 500 \\
\hline & $=$ & $=$ & $=$ & $=$ & $=$ & $=$ \\
\hline & 1475 & 1350 & 1425 & 1520 & 1650 & 1590 \\
\hline $\begin{array}{c}\text { Balance } \\
(+/)\end{array}$ & -425 & -250 & -325 & -420 & -550 & -490 \\
\hline
\end{tabular}

Based on table 1, Results of intake/24 hours of the two subjects were obtained every day $1100 \mathrm{cc}$, but on the first day the subject I intake/24 hours obtained $1050 \mathrm{cc}$. This is because the patient does not know the amount of fluid 
that is limited, so the patient does not drink $50 \mathrm{cc}$ and the patient does not experience dehydration.

Subject II had daily intake/24 hours according to the program, namely $1100 \mathrm{cc}$ and the patient did not complain of excessive thirst or dehydration. The output per 24 hours is obtained from urine output and IWL $(500 \mathrm{cc})$. In subjects I and II, the results of the first day to the third day of output fluctuated, but only decreased and increased by around $60-130 \mathrm{cc} / 24$ hours and both subjects were not dehydrated or felt complaints such as excessive thirst.

Results of fluid balance/24 hours in subject I decreased from day 1 to 3 and was negative but there were no complaints such as dehydration. Subject II on the fluid balance fluctuated and was negative but there was no indication such as edema or dehydration.

Table 2 Blood pressure results

\begin{tabular}{|l|c|c|c|}
\hline $\begin{array}{l}\text { Blood Pressure } \\
\text { (mmHg) }\end{array}$ & Day 1 & Day 2 & Day 3 \\
\hline Subject I & $158 / 75$ & $148 / 89$ & $135 / 89$ \\
\hline Subject II & $141 / 80$ & $138 / 80$ & $128 / 78$ \\
\hline
\end{tabular}

Based on table 2, the results of the blood pressure of subject I and subject II from day one to day three have decreased but there are no complaints such as dizziness.

Table 3 Pulse frequency results

\begin{tabular}{|c|c|c|c|}
\hline $\begin{array}{c}\text { Pulse Frequency } \\
\text { (x/minute) }\end{array}$ & Day 1 & Day 2 & Day 3 \\
\hline Subjek I & 73 & 89 & 89 \\
\hline Subjek II & 78 & 87 & 78 \\
\hline
\end{tabular}

In table 4.3 the pulse frequency in subject I on the second day has increased but is still within normal limits and on the third day the pulse frequency is stable. Subject II experienced an increase on the second day and experienced a reduction on the third day but was still within normal limits.

Table 4 Respiration rate results

\begin{tabular}{|l|l|l|l|}
\hline $\begin{array}{c}\text { Respiratory Frequency } \\
\text { (x/minute) }\end{array}$ & Day 1 & Day 2 & Day 3 \\
\hline Subject I & 18 & 18 & 16 \\
\hline Subject II & 18 & 16 & 16 \\
\hline
\end{tabular}

In table 4 Respiratory frequency in subject I and subject II, the respiratory rate has decreased $2 \mathrm{x} /$ minute but is still vulnerable to normal and there are no complaints such as shortness of breath.

Table 5 Result of body temperature

\begin{tabular}{|l|c|c|c|}
\hline Temperature $\left({ }^{0} \mathrm{C}\right)$ & Day 1 & Day 2 & Day 3 \\
\hline Subject I & 36.5 & 36.4 & 36.6 \\
\hline Subject II & 36.6 & 36.5 & 36.5 \\
\hline
\end{tabular}

In table 5, the results of body temperature measurements in subject I and subject II have decreased from $0-20 \mathrm{C}$, but are still within the normal temperature range..

Table 6 Daily weight results

\begin{tabular}{|c|l|l|l|}
\hline Weight (Kg) & Day 1 & Day 2 & Day 3 \\
\hline Subject I & 46 & 46 & 46 \\
\hline Subject II & 41 & 41 & 41 \\
\hline
\end{tabular}

In Table 6, the results of body weight measurements in subject I and subject II from day one to day three have no increase.

Table 7 Edema observation results

\begin{tabular}{|l|c|c|c|}
\hline Edema & Day 1 & Day 2 & Day 3 \\
\hline Subject I & No edema & No edema & No edema \\
\hline Subject II & No edema & No edema & No edema \\
\hline
\end{tabular}

Based on table 7, the results of observations of edema in subject I and subject II from the first to third day were not found to have edema.

\section{Discussion}

The results of the evaluation of subject I and subject II regarding fluid restriction carried out for 4 days were that the patient's fluid balance did not show any excess fluid problems as evidenced by the balance, vital signs and daily body weight.

On the fluid balance of subject I, namely at the time of assessment - $360 \mathrm{cc}$, first day $-425 \mathrm{cc}$, second day $-250 \mathrm{cc}$ and third $-325 \mathrm{cc}$ and subject II at the time of assessment $230 \mathrm{cc}$, first day $-420 \mathrm{cc}$, second day $-550 \mathrm{cc}$, the third day -390 
cc. Even though the fluid balance is negative, the figure accompanying a large negative value is considered to be within the tolerable limits of the subject and this negative value does not have a serious impact on the subject such as dehydration or edema.

Subject II had a greater balance than subject I. Subject II had a history of diabetes mellitus since 2007 and was uncontrolled so that she still had polyuria and in the hospital the patient received 5 units of novorapid before eating. Monitoring of intake and output has been shown to be effective in overcoming excess fluid volume in patients as evidenced by reduced manifestations of fluid overload in patients (Angrani F \& Putri A, F, 2016).

In the research of Yunanto and Rodjani (2015), it was found that the loss of fluid in DM patients was the result of an increase in glucose levels that came out through the glomerular filter. If polyuria appears not in DM patients or DM patients whose blood sugar is controlled, it is very likely that the cause of polyuria is another cause, for example disruption of renal tubular function.

Judging from the results of CCT, subject II, 23.2, including at stage 4, were lower than subject I, with CCT results of 5.5 including at stage 5 , meaning that kidney damage in subject II was lighter than subject I. In this fluid restriction, the subject was assisted and motivated by in order to avoid fluid overload by reminding and paying attention to the subject in fluid restriction settings.

Fluid regulation carried out for 4 consecutive days through the subject's daily fluid output intake observation sheet shows fluctuating fluid balance in fluid balance due to support from family, this is shown in Handayani's research (2014) that the results of respondents who get family support will be more can respond positively so that psychologically will be better able to overcome problems that arise related to things that affect compliance with fluid intake.

The use of daily intake output observation sheets has proven to be very effective in monitoring and documenting every daily intake of both subjects and their families. According to research by Anggraini and Putri (2016), the results of fluid restriction by giving intake output sheets to families are quite effective and efficient in monitoring patient intake and output.

Patient adherence to consuming fluids in subject I and subject II can lower blood pressure but subject I blood pressure is always higher than subject II because subject I has a history of hypertension and gets $1 \times 10 \mathrm{mg}$ amlodipine and $1 \times 10 \mathrm{mg}$ bioprexum which is given at $6 \mathrm{am}$.

These drugs are a class of antihypertensive drugs and hypertensive agents that are used to maintain normal blood pressure, slow the progression of kidney failure and prevent complications of coronary heart disease and cerebral vascular disease (LeMone, 2016).

Blood pressure in subjects II on the first day to the fourth day decreased gradually but not more than $10 \mathrm{mmHg}$ and the subjects did not have any significant complaints such as dizziness. This is related to the theory according to Berman and Snyder (2010), if there is a sudden drop in systolic pressure that exceeds 10 $\mathrm{mmHg}$, it usually indicates a fluid volume deficit.

According to Bayhakki (2012), almost all patients with CKD experience hypertension and can be both a cause and a result of CKD. Hypertension is the cause of CKD which is caused by high blood pressure so that it can damage the capillaries in the glomerulus which often develop.

The cause of hypertension can be caused by excess volume of fluid and sodium as well as a malfunction of the renin-angiotensin-aldosterone system. If the results of the examination show that the patient's blood pressure is normal and 
the pulse is normal with a strong and regular pulse, the patient still has a history of high blood pressure. Research conducted by Mailani (2019) found that there was a relationship between fluid intake and diastolic blood pressure $(\mathrm{p}=$ 0.013).

According to Black and Hawks (2009), an increase in the volume of excess fluid in the intravascular compartment will further cause fluid displacement from within the blood vessels to the interstitial tissue of the body.

Therefore, intervention to monitor blood pressure in patients with CKD is very important to estimate the possibility of overload. The pulse rate of subjects I and II from the first day to the last day was still stable with pulse results within normal limits (60-100x/minute), the respiratory rate of subjects I and II from the first day to the last day was stable (12-20x/minute), temperature the bodies of subjects I and II are stable within normal limits (36.537.50C).

According to Berman and Snyder (2010) and Asmadi (2008), if there is an increase in body temperature it can indicate hypernatremic dehydration and a decrease in body temperature can result in hypovolemia.

When the pulse rate increases and the pulse is weak and irregular it indicates a deficit in fluid volume and in breathing if there is a sound of breath ronkhi and rales it can indicate fluid build-up in the lungs due to excess fluid volume.

The fluid restriction greatly affects the body weight of the subject as seen from the measurement of body weight in subject I and subject II, it is found that there is no increase in body weight during fluid restriction.

According to Lewis (2011), a significant change in body weight that occurs within 24 hours is an indicator of fluid status in the body. An increase of 1 $\mathrm{kg}$ in 24 hours indicates the possibility of additional fluid accumulation in body tissues by 1 liter. This is related to the research of Instanti (2013) which shows that the mean value of the respondents' IDWG ( Interdialytic Weight Gains ) is quite high and the fluid intake is not appropriate.

This is indicated by the high fluid intake of respondents that exceeds the predetermined rules and there is a significant relationship between fluid intake and IDWG. It is recommended for nurses to educate patients about fluid regulation to prevent high IDWG.

The effect of this fluid restriction can be significant for both subjects in terms of blood pressure, pulse rate, respiratory rate, body temperature, stable weight and the absence of edema in the bodies of both subjects. The fluid restriction that the author gave to the two subjects as much as $600 \mathrm{cc} /$ day did not have a significant impact such as excessive thirst so that the patient could implement it at home.

\section{Conclusion}

Based on the results of research on the implementation of fluid restriction in overcoming excess fluid volume in both subjects with a medical diagnosis of chronic kidney disease who was treated at the Teratai Installation on North Floor VI of Fatmawati Hospital Jakarta in 2019, the authors concluded that the implementation of fluid restriction carried out for 4 days can overcome the risk of excess fluids and can be proven by the results on the fluid balance on the first day to day four subject I and II are negative.

However, even though the fluid balance results were obtained with a negative value from the first day to the fourth day which fluctuated, the patient did not experience any serious effects such as dehydration or edema. The highest fluid balance was obtained in subject II, this is because the patient had polyuria and a history of diabetes mellitus since 2007 and was not controlled and coupled with the results of subject II CCT value was greater than subject I. 
Vital signs on the first to fourth day of subjects I and II in blood pressure decreased significantly, but subject I had a history of hypertension and was receiving antihypertensive drugs. Despite a significant reduction, it was not more than $10 \mathrm{mmHg}$ and both subjects had no complaints such as dizziness. Pulse rate, respiration and temperature are in stable values and there are no serious complaints at the time of writing.

Daily body weight on the first to fourth day of subjects I and II did not gain weight or lose weight. This is because there is no additional volume of fluid in the patient's body, because both subjects followed the fluid restriction given to overcome the excess fluid volume.

It is hoped that nurses can maintain fluid restriction measures for patients and involve family members through health education and teach filling in the patient's daily intake output sheet so that the fulfillment of fluid needs can be monitored properly and excess fluid volume does not occur.

\section{Bibliography}

Angraini, $F \quad \& \quad$ Putri, AF. (2016). Monitoring of Fluid Output Intake in Patients with Chronic Renal Failure Can Prevent Fluid Overload. Journal of Nursing Volume 19 No.3 pp. 152160 ISSN: 14104490. Downloaded: https://jki.ui.ac.i d/index.php/jki/article/views/475

Bayhakki. (2012). Chronic Kidney Failure Client Nursing Care Series. Jakarta: EGC.

Berhman, SS (2010). Nursing Fundamenta ls : Concepts, processes and Practic e. Jakarta:

EGC.

Black, JM \& Hawks, JH (2009). Medical Surgical Nursing Clinical Management For Positive Out Comes. Singapore: ELSEVIER Doenges, ME (2012). Nursing Care Plans Ed. 3. Jakarta: EGC.
Angraini, $\quad F \quad \& \quad$ Putri, A.F. (2016). Monitoring of Fluid Output Intake in Chronic Renal Failure Patients Can Prevent Fluid Overload. Indonesian Journal of Nursing, 19 (3), 152-160. https://eresources.perpusnas.go.id:2111/10.7 454/jki.v19i3.475

Handayani, S. (2014). Fluid Intake Compliance in Hemodialysis Patients Reviewed by Family Support. Journal of Health Sciences Vol 9, No 19. Downloaded: https://ejournal.stikes mukla.ac.id/index.php/motor/article/ views/101

Hidayat, A.A. (2012). Introduction to Basic Human Needs. Jakarta: Salemba Medika.

Isroin, L. (2016). Fluid Management In Hemodialysis Patients To Improve Quality Of Life . Ponorogo: Ummuh Ponorogo Press.

Istanti, Y.P. (2013). Relationship Between Fluid Input and Interdialytic Weight Gains (IDWG) in Chronic Kidney Disease Patients in the Hemodialysis Unit of PKU Muhammadiyah Hospital Yogyakarta. Journal of Profession, Vol.10 of Science Nursing University of Muhammadiyah Yogyakarta. Dow nloaded: https://ejournal.stikepku.ac.i d/index.php/mpp/article/view/60

Jamiatun, Elgia, K. \& Syarif, MNO. (2015). Analysis of Factors Associated with Compliance with Fluid Restrictions in Chronic Kidney Failure Patients Underwent Hemodialysis at Jakarta Sukapura Hospital. Journal of Health Sciences Vol. 5, No.1 ISSN: $1693-$ 6868. Downloaded: http://ejournal.ur indo.ac.id/index.php/index/index

Kozier, et al. (2010). Textbook of Fundamental Nursing Concepts, Processes \& Practices Ed.7 Vol.2. Jakarta: EGC. 
LeMone, P. (2016). Textbook of Medical Surgical Nursing: Elimination Disorders . Jakarta: EGC.

Lewis, SL (2011). Medical Surgical Nursing: Assessment And Management Of Clinical Problems. Singapore:ELSIVIER

Mailani. F. (2019). Relationship between Fluid Intake and Increased Blood Pressure in Chronic Renal Failure (CRF) Patients Undergoing Hemodialysis. NERS Journal of Nursing , 14 (2), 72-80. https://eresources.perpusnas.go.id:2111/10.2 5077/njk.14.2.72-80.2018

Melianna, R. \& Wiarsih, W. (2013). Relationship of Compliance with Fluid Restrictions on Overload in Patients with Post-Hemodialysis Chronic Renal Failure at Fatmawati Central General Hospital. Journal of Nursing, Faculty Nursing, University Indonesia. Downloaded: http://lib.ui. ac.id/

Muttaqin, A. \& Sari, K. (2014). Nursing Care for Urinary System Disorders . Jakarta: Salemba Medika.

Nursalam. (2008). Concept and Application of Nursing Research Methodology. Thesis Guidelines, Thesis, and Nursing Research Instruments. Jakarta: Salemba Medika.

O'Callaghan, CA (2009). At a Glance The Kidney System Second Edition . Jakarta: Erlangga.

Potter \& Perry. (2006). Textbook of Nursing Fundamentals Concepts, Processes, and Practices Ed.4. Jakarta: EGC.

Rubestein, D., Wayne, D \& Bradley. (2007). Lecture Notes:

\section{Clinical}

Medicine 6th Edition . Jakarta:

Erlangga.

Suharyanto, T. (2009). Nursing Care for Clients With Urinary System Disorders . Jakarta: TIM.

Ulfah, M., Yuniarti \& Rahayuni, A. (2018). Effects of Nutrition Counseling T erhadap Knowledge and Compliance restricted fluid intake in patients with Chronic Kidney Disease (CKD) in hospitals Abdul Wahab Sjahranie Samarinda . Journal of Nutrition Vol. 20, No.1 ISSN: 1693-

945X. Downloaded: https://repositor y.poltekkessmg.ac.id/index.php? $\mathrm{p}=\mathrm{s}$ how_detail\&id=14367\&key words

Wahid, A., \& Suprapto, I. 2012. Documentation of Nursing Process. Yogjakarta: Nuha Medika.

Wulan, SN \& Emaliyawati, E. 2018. Compliance with Restrictions on Fluid and Low Salt (Sodium) Diet in CKD Patients undergoing Hemodialysis; The Health Belief Model Perspective. Falatehan Health Journal, 5 (3) (2018) 99106 ISSN 2088-673X e-ISSN 25978667.

Downloaded: https://media.neliti.co $\mathrm{m}$

Yunanto, A \& Rodjani, A. 2015. Biomarkers of predictors of polyuria incidence in post-kidney transplant patients. Journal of the Department of Urology, Dr. Cipto Mangunkosumo Hospital Vol 3, No 3 . Downloaded: http://journal.ui.ac.id/ 